\title{
ANALISIS KEMANDIRIAN SISWA \\ PADA PEMBELAJARAN \\ MATEMATIKA DENGAN \\ MENERAPKAN TEORI BELAJAR \\ HUMANISTIK
}

\author{
Anzora \\ anzora199@gmail.com \\ Program Studi Pendidikan Matematika \\ FKIP- Universitas Abulyatama \\ 2017
}

\begin{abstract}
Abstrak
Dalam dunia pendidikan, yang harus diperhatikan terhadap siswa adalah karakter dan perbedaan individual. Siswa diarahkan untuk dapat mengembangkan potensi kemandiriannya tanpa ada tekanan, paksaan, ataupun kekerasan dari guru. Penelitian ini bertujuan untuk mengetahui kemandirian siswa dan respon siswa kelas X SMA Negeri 1 Teluk Dalam dengan penerapan teori belajar humanistik pada materi persamaan dan pertidaksamaan kuadrat. Subjek penelitiannya adalah seluruh siswa kelas X SMA Negeri 1 Teluk Dalam. Pengumpulan data menggunakan angket dan lembar observasi. Data diolah dengan menggunakan analisis persentase. Hasil penelitian menunjukan bahwa, tingkat kemandirian siswa dengan menerapkan teori belajar humanistik dalam proses pembelajaran matematika pada materi persamaan dan pertidaksamaan kuadrat berada pada kategori mandiri, pada lima indikator kemandirian siswa yaitu ketidaktergantungan terhadap orang lain $73,9 \%$, disiplin $86,95 \%$, tanggungjawab 73,9\%, inisiatif $86,95 \%$, dan kontrol diri 78,25\%. Sedangkan indikator percaya diri $65,2 \%$ berada pada kategori cukup mandiri, respon siswa terhadap penerapan teori belajar humanistik dalam proses pembelajaran adalah positif dengan persentase $72 \%$.

Kata kunci: teori belajar humanistik, kemandirian siswa
\end{abstract}

\begin{abstract}
In education field, things must be considered against students are the character and individual differences. Students are directed to develop their self-reliance potential without any pressure, coercion, or violence from teachers. This study aims to determine the independence of students and the response of students of class X SMA Negeri 1 Teluk Dalam with the application of humanistic learning theory on the topic of equation and quadratic inequality. Research subjects are all students of grade X SMA Negeri 1 Teluk Dalam. Data collection method used are questionnaires and observation sheets. The data is processed by using percentage analysis. The results showed that the level of student independence by applying the theory of humanistic learning in the process of learning mathematics on the topic of equation and quadratic inequality is in the independent category, the five indicators of independence of students: the dependence of others $73.9 \%$, discipline $86.95 \%$, responsibility $73.9 \%, 86.95 \%$ initiative, and self-control $78.25 \%$. While self-confident indicator $65.2 \%$ are
\end{abstract}




\section{JURNAL GANTANG. September 2017; II(2): 99 - 103 \\ p-ISSN. 2503-0671 \\ e-ISSN. 2548-5547}

in the self-sufficient category, student's response to application of humanistic learning theory in the learning process is positive with the percentage of $72 \%$.

Keywords: humanistic learning theory, student's independency

\section{Pendahuluan}

Konsep pendidikan nasional, bahwa core value pendidikan nasional adalah independency (kemandirian). Kemandirian dalam hal ini merupakan karakteristik individu sehingga mampu membuat keputusan sendiri setelah secara matang dan konsekuen mampu mensistem dan mensinergikan lingkungannya secara baik (Mustofa Kamil, 2010: 133).

Kemandirian dalam belajar adalah aktivitas belajar yang berlangsungnya dengan dorongan kemauan sendiri, pilihan sendiri dan tanggung jawab sendiri oleh siswa. Kemandirian dalam belajar sangat diperlukan untuk membentuk pribadi siswa yang percaya diri, bertanggung jawab dan mampu mengatasi masalah. Kemandirian belajar siswa akan mengantarkan siswa untuk belajar menganalisa dan mengembangkan pikiran kritis.

Pembelajaran dalam pendekatan humanistik, dipahami sebagai pembelajaran yang mengarah pada proses memanusiakan manusia. Menurut Baharuddin dan Moh. Makin (2007:114), menegaskan bahwa pendidikan yang memanusiakan manusia adalah proses membimbing, mengembangkan, dan mengarahkan potensi dasar manusia baik jasmani, maupun rohani secara seimbang dengan menghormati nilai humanistik yang lain. Rumusan Masalah

Adapun rumusan masalah dalam penelitian ini adalah:

a. Bagaimana kemandirian siswa pada pembelajaran matematika dengan menerapkan teori belajar humanistik?

b. Bagaimana respon siswa terhadap model pembelajaran dengan menerapkan teori belajar humanistik?

Sedangkan tujuan penelitian ini adalah sebagai berikut: a. Untuk mengetahui kemandirian siswa pada pembelajaran matematika dengan menerapkan teori belajar humanistik

b. Untuk mengetahui respon siswa terhadap model pembelajaran matematika dengan menerapkan teori belajar humanistik

\section{Metode Penelitian}

Penelitian ini menggunakan jenis penelitian kualitatif deskriptif. Adapun yang dimaksud dengan penelitian kualitatif adalah salah satu prosedur penelitian yang menghasilkan data deskriptif berupa ucapan, tulisan, atau prilaku orang-orang yang diamati.

Subjek penelitiannya adalah seluruh siswa kelas X di SMA Negeri 1 Teluk Dalam. Berdasarkan informasi yang peneliti dapatkan dari hasil wawancara awal dengan Kepala SMA Negeri 1 Teluk Dalam, siswa kelas X SMA Negeri 1 Teluk Dalam tahun ajaran 2016/2017 seluruhnya berjumlah 23 orang siswa.

Pengumpulan data dalam penelitian ini dilakukan dengan berbagai teknik pengumpulan data meliputi angket kuisoner kemandirian siswa, angket respon siswa, dan dokumentasi. Instrumen penelitian yang digunakan dalam studi ini adalah - Lembar angket

Dalam penelitian ini format alat ukur yang dipilih untuk menyajikan butir-butir instrumen adalah format pilihan terbatas. Dengan menggunakan skala likert 5-titik maka untuk tiaptiap butir memiliki 5 pilihan jawaban yakni Sangat Setuju (SS), Setuju (S), Kurang Setuju (KS), Tidak Setuju (TS), dan Sangat Tidak Setuju (STS). Penskoran pada pernyataan positif dilakukan dengan memberikan skor 5 untuk SS, 4 untuk S, 3 untuk KS, 2 untuk TS, dan 1 untuk STS. Sedangkan untuk pernyataan negatif, penskoran dilakukan dengan memberikan skor 1 untuk SS, 2 untuk S, 3 untuk KS, 4 untuk TS, dan 5 untuk STS. 
Tabel 1. Tabel Skor Butir-Butir Instrumen

\begin{tabular}{llllll}
\hline & SS & S & KS & TS & STS \\
\hline $\begin{array}{l}\text { Positif } \\
(+)\end{array}$ & 5 & 4 & 3 & 2 & 1 \\
\hline $\begin{array}{l}\text { Negatif } \\
(-)\end{array}$ & 1 & 2 & 3 & 4 & 5 \\
\hline
\end{tabular}

Kemandirian dilihat dari berbagai indicator pendefinisi. Enam indikator kemandirian belajar siswa, yaitu: ketidaktergantungan terhadap orang lain, memiliki kepercayaan diri, berperilaku disiplin, memiliki rasa tanggungjawab, berperilaku berdasarkan inisiatif sendiri, dan melakukan kontrol diri. Kisi-kisi instrumen kemandirian belajar siswa dapat dilihat dalam gambar 2 .

- Angket Respon Siswa

Lembar angket siswa berupa pertanyaan tertulis yang diajukan kepada siswa untuk mengetahui respon siswa terhadap pembelajaran matematika dengan menerapkan teori belajar humanistik. Adapun penilaian respon siswa berupa: Sangat Setuju (SS), Setuju (S), Tidak Setuju (TS), Sangat Tidak setuju (STS).

\section{Tabel 2. Kisi-kisi Instrumen Kemandirian Belajar Siswa}

\begin{tabular}{|c|c|c|}
\hline Indikator & $\begin{array}{l}\text { No. } \\
\text { Butir } \\
\text { Soal } \\
\end{array}$ & $\begin{array}{l}\text { Jumlah } \\
\text { Soal }\end{array}$ \\
\hline $\begin{array}{l}\text { Ketidakterg } \\
\text { antungan } \\
\text { terhadap } \\
\text { orang lain. }\end{array}$ & $\begin{array}{l}1(-), \\
4(-), \\
6(+), \\
16(+)\end{array}$ & 4 \\
\hline $\begin{array}{l}\text { Memiliki } \\
\text { kepercayaan } \\
\text { diri. }\end{array}$ & $\begin{array}{l}8(+) \\
10(-), \\
17(+)\end{array}$ & 3 \\
\hline $\begin{array}{l}\text { Berperilaku } \\
\text { disiplin. }\end{array}$ & $\begin{array}{l}11(+), \\
12(-), \\
18(+)\end{array}$ & 3 \\
\hline $\begin{array}{l}\text { Memiliki } \\
\text { rasa } \\
\text { tanggungja } \\
\text { wab. }\end{array}$ & $\begin{array}{l}7(+), \\
13(-), \\
14(+)\end{array}$ & 3 \\
\hline $\begin{array}{l}\text { Berperilaku } \\
\text { berdasarkan } \\
\text { inisiatif } \\
\text { sendiri. }\end{array}$ & $\begin{array}{l}2(+), \\
3(+)= \\
5(-)= \\
20(+)\end{array}$ & 4 \\
\hline \multirow[t]{2}{*}{$\begin{array}{l}\text { Melakukan } \\
\text { kontrol diri. }\end{array}$} & $\begin{array}{l}9(+) \\
15(-), \\
19(+)\end{array}$ & 3 \\
\hline & $\begin{array}{l}\text { Total } \\
\text { Jumla } \\
\text { h Soal }\end{array}$ & 20 \\
\hline
\end{tabular}

Analisis data dilakukan pada kemandirian siswa dan respon siswa. Untuk mengetahui tingkat kemandirian siswa, peneliti menggunakan analisis data persentase, yaitu:

$$
P=\frac{n}{N x S} \times 100 \%
$$

Dengan

$\mathrm{P}=$ Persentase

$\mathrm{n}=$ Jumlah scor yang diperoleh

$\mathrm{N}=$ Jumlah scor maksimal

$\mathrm{S}=$ Jumlah soal/aspek

(Arikunto: 2006)

Adapun penggolongan persentase secara kolaboratif data kemandirian siswa yang menyangkut ketidaktergantungan terhadap orang lain, memiliki kepercayaan diri, berperilaku disiplin, memiliki rasa tanggungjawab, berperilaku berdasarkan inisiatif sendiri, dan melakukan kontrol diri, adalah:

$$
\begin{array}{ll}
90 \%-100 \% & =\text { Sangat Mandiri } \\
70 \%-89 \% & =\text { Mandiri } \\
60 \%-69 \% & =\text { Cukup Mandiri } \\
50 \%-59 \% & =\text { Kurang Mandiri } \\
0 \%-49 \% & =\text { Sangat Kurang Mandiri }
\end{array}
$$

(Arikunto: 2006)

Sedangkan data respon siswa diperoleh melalui angket, dianalisis menggunakan statistik deskriptif dengan persentase. Menurut Zubaidah dan Kumar (dalam Wahyuni, 2007) persentase dari setiap respon siswa diperoleh dengan membagi jumlah respon siswa tiap aspek yang muncul dengan jumlah seluruh siswa dikali seratus persen. Secara sistematis persentase dari setiap respon siswa dapat ditulis:

$$
\text { Persentase }(\%)=\frac{n}{N} x 100 \%
$$

Menurut Suhardinsyah (2014) respon siswa dikatakan efektif jika jawaban siswa terhadap pertanyaan positif untuk tiap aspek yang 
JURNAL GANTANG. September 2017; II(2): 99 - 103

p-ISSN. 2503-0671

e-ISSN. 2548-5547

direspon pada setiap komponen pembelajaran diperoleh persentase $\geq 70 \%$.

\section{Hasil dan Pembahasan}

\section{Analisis Data Kemandirian Siswa}

Berdasarkan angket kemandirian yang diisi oleh 23 siswa kelas X SMA Negeri 1 Teluk Dalam, diperoleh nilai persentase kemandirian siswa yang disajikan dalam grafik berikut ini:

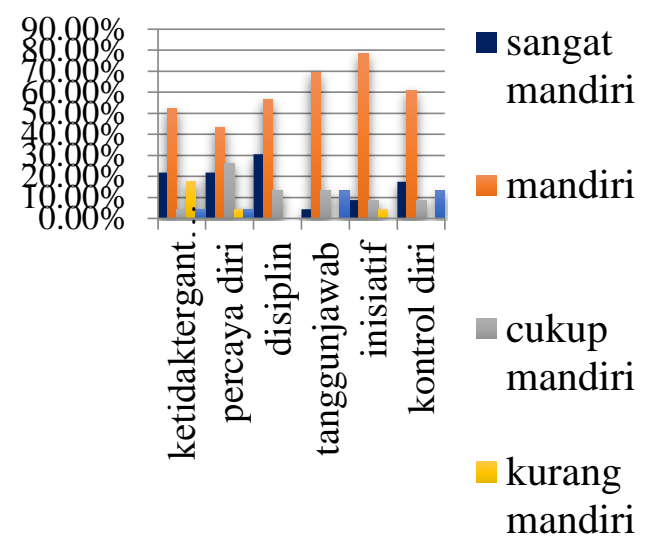

Gambar 1. Nilai persentase kemandirian

Secara umum jika dilihat dari keseluruhan indikator kemandirian siswa dapat dikatakan bahwa tingkat kemandirian siswa dengan menerapkan teori belajar humanistik berada pada kategori mandiri. Dimana terdapat $\geq 70 \%$ siswa telah berada pada kategori mandiri dan $\leq 30 \%$ siswa berada pada kategori cukup mandiri, kurang mandiri, dan sangat kurang mandiri.

Tabel 3. Persentase keseluruhan kemandirin siswa

\begin{tabular}{|l|l|l|}
\hline Kategori & $\begin{array}{l}\text { Jumlah } \\
\text { Siswa }\end{array}$ & $\begin{array}{l}\text { Persentase } \\
\%\end{array}$ \\
\hline $\begin{array}{l}\text { Sangat } \\
\text { Mandiri }\end{array}$ & 0 & $0 \%$ \\
\hline Mandiri & 18 & $78,26 \%$ \\
\hline $\begin{array}{l}\text { Cukup } \\
\text { Mandiri }\end{array}$ & 3 & $13,04 \%$ \\
\hline $\begin{array}{l}\text { Kurang } \\
\text { Mandiri }\end{array}$ & 2 & $8,69 \%$ \\
\hline $\begin{array}{l}\text { Sangat } \\
\text { Kurang } \\
\text { Mandiri }\end{array}$ & 0 & $0 \%$ \\
\hline Jumlah & 23 & $100 \%$ \\
\hline
\end{tabular}


mencapai persentase $72 \%$ setuju atau sangat setuju. Sehingga, secara umum pembelajaran matematika dengan penerapan teori belajar humanistik pada materi persamaan dan pertidaksamaan kuadrat mendapat respon baik dari siswa.

\section{Penutup}

Setelah menganalisis dan membahas hasil penelitian yang berkenaan dengan analisis kemandirian siswa dengan menerapkan teori belajar humanistik dalam proses pembelajaran matematika maka penulis dapat menarik beberapa kesimpulan diantaranya sebagai berikut:

1. Tingkat kemandirian siswa dengan menerapkan teori belajar humanistik dalam proses pembelajaran matematika pada materi persamaan dan pertidaksamaan kuadrat berada pada kategori mandiri, pada lima indikator kemandirian siswa yaitu ketidaktergantungan terhadap orang lain $73,9 \%$, disiplin $86,95 \%$, tanggungjawab $73,9 \%$, inisiatif $86,95 \%$, dan kontrol diri $78,25 \%$. Sedangkan indikator percaya diri $65,2 \%$ berada pada kategori cukup mandiri.

2. Respon siswa terhadap penerapan teori belajar humanistik dalam proses pembelajaran adalah positif dengan persentase $72 \%$.

\section{Daftar Pustaka}

Arikunto, S. (2006). Prosedur Penelitian Suatu Pendekatan Praktik (edisi revisi VI). Jakarta: Rineka Cipta.

Baharudin \& Esa N. W. (2007). Teori Belajar Dan Pembelajaran, Yogyakarta: Ar-Ruzz Media.

Baharudin dan Moh. Makin. (2007). Pendidikan Humanistik (Konsep, Teori, dan Aplikasi Dalam Dunia Pendidikan). Yogyakarta: Ar-Ruzz Media.

Listyani E \& Hidayati K (2010). Improving Instruments of Students' Self-Regulated Learning. Yogyakarta: FMIPA UNY Mathematics Education Department.

R. agung, S. P. \& Latifatul, C. (2009). Teori Humanisme. Makalah. Malang.

Syah, Muhibbin. (2006). Psikologi Belajar. Jakarta: PT. Raja Grafindo Persada.
Suhardinsyah, Said. (2014). Penerapan Model Kooperatif Tipe STAD Pada Materi Persamaan Garis Lurus Di Kelas VIII SMP PKPU. Banda Aceh: Skripsi Universitas Syiah Kuala Fakultas Keguruan dan Ilmu Pendidikan: tidak diterbitkan. 
JURNAL GANTANG. September 2017; II(2): 99 - 103

p-ISSN. 2503-0671

e-ISSN. 2548-5547 